\title{
Length variation in HIV-1 gp120 as the product of DNA misalignment mechanism
}

\author{
Silvia Guglietta, Giuseppe Pantaleo, Cecilia Graziosi \\ From $16^{\text {th }}$ International Symposium on HIV and Emerging Infectious Diseases \\ Marseille, France. 24-26 March 2010
}

\section{Background}

To determine whether misalignment structures such as duplications, repeats, and palindromes are associated to insertions/deletions (indels) in gp120, indicating that indels are indeed frameshift mutations generated by DNA misalignment mechanism.

\section{Methods}

Cloning and sequencing of a fragment of HIV-1 gp120 spanning $\mathrm{C} 2-\mathrm{C} 4$ derived from plasma RNA in 12 patients with early chronic disease and naïve to antiretroviral therapy.

\section{Results}

Indels in V4 involved always insertion and deletion of duplicated nucleotide segments, and AAT repeats, and were associated to the presence of palindromic sequences. No duplications were detected in V3 and C3. Palindromic sequences occurred with similar frequencies in V3, C3 and V4; the frequency of palindromes in individual genes was found to be significantly higher in structural (gp120, p $\leq 3.00 \mathrm{E}-7$ ) and significantly lower in regulatory (Tat, $\mathrm{p} \leq 9.00 \mathrm{E}-7$ ) genes, as compared to the average frequency calculated over the full genome.

\section{Discussion}

Indels in V4 are associated to misalignment structures (i.e. duplications repeat and palindromes) indicating DNA misalignment as the mechanism underlying length variation in V4. The finding that indels in V4 are caused by DNA misalignment has some very important implications: 1) indels in V4 are likely to occur in proviral DNA (and not in RNA), after integration of HIV into the host genome; 2) they are likely to occur as progressive modifications of the early founder virus during chronic

\footnotetext{
* Correspondence: cecilia.graziosi@chuv.ch
}

CHUV, Lausanne, Switzerland infection, as more and more cells get infected; 3) frameshift mutations involving any number of base pairs are likely to occur evenly across gp 120 ; however, only those mutants carrying a functional gp120 (indels as multiples of three base pairs) will be able to perpetuate the virus cycle and to keep spreading through the population.

Published: 11 May 2010

\section{doi:10.1186/1742-4690-7-S1-P21}

Cite this article as: Guglietta et al:: Length variation in HIV-1 gp120 as the product of DNA misalignment mechanism. Retrovirology 2010 7(Suppl 1):P21.
Submit your next manuscript to BioMed Central and take full advantage of:

- Convenient online submission

- Thorough peer review

- No space constraints or color figure charges

- Immediate publication on acceptance

- Inclusion in PubMed, CAS, Scopus and Google Scholar

- Research which is freely available for redistribution

Submit your manuscript at www.biomedcentral.com/submit 